\title{
PENGARUH STORY TELLING TERHADAP TINGKAT KECEMASAN ANAK PRASEKOLAH YANG MENJALANI HOSPITALISASI DI RSUP DR.M.DJAMIL PADANG TAHUN 2017
}

\author{
Amelia Susanti ${ }^{1}$, Hendika Safitri ${ }^{2}$ \\ ${ }^{1}$ STIKes Alifah, Padang 25000 \\ Email: ameliaaska@gmail.com \\ ${ }^{2}$ Sekolah Tinggi Ilmu Keperawatan Alifah Padang \\ Email: stikes_alifah@yahoo.com
}

\begin{abstract}
ABSTRAK
Penelitian ini bertujuan untuk mengetahui apakah ada pengaruh story telling terhadap tingkat kecemasan anak prasekolah yang menjalani hospitalisasi di RSUP Dr.M.DJAMIL Padang Tahun 2017.

Jenis penelitian ini menggunakan pra-eksperiment dengan pendekatan one group pretest-posttest Design. Penelitian telah dilakukan pada tanggal 16 - 30 Agustus 2017. Populasi dalam penelitian ini bersifat infinit, jumlah sampel adalah 10 orang anak usia prasekolah yang menjalani hospitalisasi di ruang akut dan kronik di RSUP Dr.M.DJAMIL Padang. 40\% anak mengalami tingkat kecemasan tinggi, $60.0 \%$ anak mengalami tingkat kecemasan sedang. Sesudah terapi Storry Telling ditemukan $20.0 \%$ anak mengalami tingkat kecemasan sedang dan $80.0 \%$ anak mengalami tingkat kecemasan rendah. Ada pengaruh story telling terhadap tingkat kecemasan anak prasekolah yang menjalani hospitalisasi di RSUP Dr.M.DJAMIL Padang Tahun 2017 ( $\mathrm{p}=0,007$ ).

Dapat disimpulkan bahwa tingkat kecemasan pada anak dapat dikurangi dengan melakukan terapi storry telling. Disarankan kepada petugas kesehatan yang merawat anak untuk menerapkan terapi story telling pada anak sehingga dapat menurunkan tingkat kecemasan pada anak.
\end{abstract}

Kata kunci : Terapi Story Telling, Tingkat Kecemasan

\begin{abstract}
Storry telling is a non-pharmacological therapy that aims to make children happy so as to reduce anxiety levels in children. This study aims to determine whether there is influence story telling on the anxiety level of preschool children who underwent hospitalization in Dr.M.DJAMIL Padang Hospital Year 2017.

Type of this research is Quasi experiment with approaches One group pretest and posttest. The research was conducted in 16 until 30 august 2017. The population in this study is infinite, the number of samples in this study were 10 Preschool children who underwent hospitalization at Dr.M.DJAMIL Padang Hospital with various disease. the sampling technique used insidental sampling. Instrument the research using observation sheet (The results of anxiety level measurement).

Before Storry Telling therapy was found as many as 4 people (40\%) children experience high levels of anxiety and as many as 6 people (60.0\%) of children experience moderate anxiety level. After Storry Telling therapy was found as many as 2 people (20.0\%) children experience moderate anxiety level and as many as 8 people (80.0\%) of children experience low anxiety levels. There is influence story telling to the level of anxiety of preschool children who undergo hospitalization in Dr.M.DJAMIL Padang Hospital in 2017 (p = 0,007).

Conclusion :Can be concluded that the level of anxiety in children can be reduced by doing storry telling therapy. It is recommended that health care workers take care of children to implement story telling therapy in children so as to reduce anxiety levels in children.
\end{abstract}

Keyword : Story Telling Therapy, Anxiety Level 


\section{PENDAHULUAN}

Anak adalah dambaan setiap individu dan sudah berkeluarga. Setiap keluarga mengharapkan anaknya kelak dapat tumbuh dan berkembang secara optimal (sehat fisik, mental, kognitif, sosial), sehingga dapat dibanggakan, serta berguna bagi nusa dan bangsa.Anak sebagai asset bangsa harus diberikan perhatian yang dimulai dari sejak dalam kandungan sampai anak menjadi manusia dewasa (Soetjiningsih, 2015).Saat anak berada di dalam kandungan hingga dewasa, anak akan mengalami tahap tumbuh kembang yang dibagi menjadi tahap kognitif, tahap psikoseksual, dan tahap psikososial(Hidayat, 2009).

Periode kanak-kanak awal merupakan tahap tumbuh kembang yang terdiri dari usia 1-3 tahun (todler), dan usia 3-6 tahun (prasekolah). Pada usia prasekolah keterampilan motorik anak sudah berkembang secara signifikan sesuai dengan tahapan tumbuh kembang anak. Pada usia ini anak sudah dapat berjalan, berlari, dan melompat. Perkembangan konsep diri pada usia prasekolah sudah dimulai pada usia 3-6 tahun, dan kemampuan interaksi sosial anak sudah lebih luas, sehingga anak usia prasekolah dapat mempersiapkan diri untuk memasuki dunia sekolah (Supartini, 2014).

Sehat dalam keperawatan anak adalah sehat dalam rentang sehat sakit.Sehat dapat diartikan juga sebagai keadaan sejahtera yang optimal baik fisik, mental, dan sosial yang harus dicapai anak untuk meningkatkan pertumbuhan dan perkembangan anak secara optimal sesuai dengan usianya (Supartini, 2014).Rentang sehat sakit adalah suatu alat ukur untuk menilai status kesehatan yang bersifat dinamis dalam setiap waktu yang membutuhkan bantuan perawat secara langsung dan tidak langsung, seperti jika anak berada pada rentang sehat maka upaya anak untuk meningkatkan derajat kesehatan sampai mencapai taraf kesejahteraan (fisik, sosial, dan spiritual), dan sebaliknya, perawat akan memberikan bantuan dan dukungan kepada pasien yang meninggal atau dalam kondisi kritis (Hidayat, 2009).

Kondisi kritis yang diakibatkan oleh bencana (gempa bumi, kecelakaan motor, dll) atau hal darurat lainnya (tindakan pembedahan), dan mengharuskan anak untuk tinggal dirumah sakit, menjalani terapi, beserta perawatan sampai pemulangan kembali kerumah disebut dengan hospitalisasi. Hospitalisasi rawat inap pada pasien anak dapat menyebabkan kecemasan dan stress.Stress pada anak dapat dicegah dengan cara memberikan penjelasan tentang prosedur pengobatan dan manfaat hospitalisasi pada anak (Nursalam, dkk 2008).

Selain menjelaskan mengenai prosedur pengobatan, stress dan kecemasan pada anak dapat dicegah dengan cara terapi bermain yang terdiri dari social affective play, sense pleasure play, games, dramatic play, dan cooperative play (storry telling) (Supartini, 2014). Storry tellingmerupakan sebuah terapi non farmakologi atau disebut juga dengan terapi tanpa menggunakan obat, yang bertujuan untuk membuat anak menjadi senang atau dijadikan suatu hiburan pada saat dirawat dirumah sakit selain itu storry telling bisa membantu perkembangan berbahasa dan berinteraksi dengan orang lain. (Latif dkk, 2014).

Survei WHO tahun 2008 menyatakan hampir $80 \%$ anak mengalami perawatan di rumah sakit (WHO, 2008). Di Amerika Serikat, diperkirakan lebih dari 5 juta anak menjalani hospitalisasi karena prosedur pembedahan dan lebih dari $50 \%$ dari jumlah tersebut, anak mengalami kecemasan dan stres. Diperkirakan juga lebih dari 1,6 juta anak dan anak usia antara 2-6 tahun menjalani hospitalisasi disebakan karena injury dan berbagai penyebab lainnya (Disease Control, National Hospital Discharge Survey (NHDS), 2004Kaluas Inggrith, dkk. 2015).

Angka kesakitan anak di Indonesia di daerah perkotaan menurut kelompok usia 0-4 tahun sebesar $25,8 \%$, usia 5-12 tahun sebanyak $14,91 \%$, usia $13-15$ tahun sekitar 9,1\%, usia 16-21 tahun sebesar $8,13 \%$. Angka kesakitan anak usia 0-21 tahun apabila dihitung dari keseluruhan jumlah penduduk adalah 14,44\%(Survei Kesehatan Nasional (Susenas), 2010).

Berdasarkan data RSUP DR.M Djamil Padang yang merupakan rumah sakit rujukan tipe $\mathrm{A}$ yang berada di Sumatera Barat diperoleh jumlah anak yang di rawat di ruang rawat inap mengalami peningkatan dari tahun ketahun yaitu pada tahun 2014 adalah 3059 anak, pada tahun 2015 adalah 3518 anak, dan 1 tahun terakhir pada tahun 2016 terdapat peningkatan jumlah anak sakit yang di rawat di RSUP Dr.M Djamil 3635 anak (RSUP Dr.M Djamil Sumbar, 2017).

Hasil penelitian Rupdi Lumbansiantar (2012) yang berjudul pengaruh storry telling terhadap tingkat kecemasan akibat hospitalisasi pada anak usia prasekolah di RSUD Bekasi menunjukan semua anak yang dihospitalisasi memiliki tingkat kecemasan yang berbeda- beda terdiri dari 21 orang $(56,4 \%)$ kecemasan sedang, 11 orang $(28,2 \%)$ kecemasan ringan, 6 orang $(15,4 \%)$ kecemasan berat. Dan setelah dilakukan terapi bermain storry telling pada anak yang di hospitalisasi menunjukan bahwa 21 orang $(53,8 \%)$ pada kecemasan ringan, 14 orang $(35,9 \%)$, tidak cemas 4 orang $(10,3 \%)$, dan tidak ditemukan lagi anak yang mengalami kecemasan berat.

Hasil penelitian Ngakan Putu Siwi Edisaputra, dkk (2012) Hasil penelitian Lenny Irmawaty (2013)yang berjudul pengaruh storry telling terhadap tingkat kecemasan akibat hospitalisasi pada anak usia prasekolah di RSUD Bekasi menunjukan kecemasan anak sebelum di berikannya story telling rata-rata tingkat kecemasan responden berada pada kategori cemas sedang dengan persentase $56.4 \%$, setelah diberikannya story telling rata-rata tingkat kecemasan responden berada pada kategori cemas ringan dengan persentase $53.8 \%$. 
Berdasarkan survey awal yang peneliti lakukan di Ruang Rawat Inap Anak RSUP Dr.M. Djamil Padang pada tanggal 13 Maret 2017, dari 10 anak yang dirawat 2 orang anak usia 6 tahun, dan 4 orang anak usia 5 tahun mengalami tingkat kecemasan sedang (mulai berkeringat, nada suara tinggi, pola tidur berubah), 1 orang anak usia 3 tahun, dan 1 orang lagi anak usia 4 tahun mengalami tingkat kecemasan tinggi (kontak mata yang buruk, dan berteriak), serta 2 orang anak usia 4 tahun mengalami tingkat kecemasan ringan (anak tampak rileks, tampak gelisah tapi sedikit, dan penuh perhatian).

Angka rawatan anak usia prasekolah tiga bulan terakir di RSUP DR.M Djamil Padang 58,7\% anak usia prasekolah, 23,8\% anak usia sekolah, 17,4\% anak usia remaja. Hasil wawancara yang dilakukan dengan perawat di ruang rawat inap anak RSUP DR.M Djamil Padang, terapi bermain sudah mulai diterapkan tetapi hanya dilakukan jika ada mahasiswa yang praktek, dan belum ada ruangan khusus terapi bermain. Hasil observasi terhadap anak, khususnya pada anak prasekolah diruang perawatan anak di RSUP DR.M Djamil Padang yaitu anak tampak ketakutan, anak tampak cemas, rewel, menangis, tidak mau didekati oleh perawat, gelisah, gangguan rasa nyaman, dan kontak mata yang buruk.

Kecemasan pada anak yang menjalani hospitalisasi disebabkan karena beberapa alasan, seperti cemas akan tindakan medis yang akan dilakukan oleh tim kesehatan seperti cemas untuk disuntik, cemas untuk dipasangkan infus,dll, cemas untuk ditinggal sendiri, dan cemas akan luka ditubuhnya. Terapi storry telling ini berguna untuk mengatasi kecemasan pada anak usia prasekolah yang menjalani hospitalisasi agar anak usia prasekolah tersebut tidak menjadi stress, sehingga dapat membantu proses penyembuhan seorang anak yang menjalani hospitalisasi di RSUP DR.M Djamil Padang. RSUP DR.M Djamil Padang merupakan rumah sakit rujukan tipe A yang berada di Sumatera Barat, ASKES nya tingkat satu, fasilitas medisnya lebih lengkap, tenanga kesehatannya banyak, sehingga anak yang menjalani hospitalisasi disana lebih banyak khususnya anak usia prasekolah. Berdasarkan riset terkait yang penulis dapat, di Indonesia terapi storry telling baru diteliti di beberapa tempat saja seperti di RSUD Bekasi, dan Rumah Sakit Dr. Soeradji Tirtonegoro Klaten, dan belum ada yang meneliti di Sumatera Barat.

Berdasarkan uraian-uraian diatas maka peneliti berkeinginan untuk meneliti tentang" Apakah ada pengaruh story telling terhadap tingkat kecemasan anak prasekolah yang menjalani hospitalisasi di RSUP Dr.M.Djamil Padang Tahun 2017?".

\section{METODA PENELITIAN}

Jenis penelitian ini menggunakan praeksperiment dengan pendekatan one group pretestposttest Design. Penelitian telah dilakukan pada tanggal 16 - 30 Agustus 2017. Populasi dalam penelitian ini bersifat infinit, jumlah sampel adalah 10 orang anak usia prasekolah yang menjalani hospitalisasi di ruang akut dan kronik di RSUP Dr.M.DJAMIL Padang. Pengumpulan data menggunakan lembar observasi dan wawancara terhadap tingkat kecemasan anak. Pengolahan data melalui analisa data secara univariat dan bivariat yang dianalisis dengan statistic wilcoxon.

\section{HASIL}

a. Analisa Univariat

Analisa univariat ini digunakan untuk melihat distribusi frekuensi tingkat kecemasan sebelum dan sesudah Terapi Storry Telling pada anak prasekolah yang menjalani hospitalisasi di Dr. M. Djamil Padang Tahun 2017, sebagai mana terlihat pada tabel berikut ini :

1. Tingkat Kecemasan Sebelum Terapi Storry Telling

Tabel 4.1

Distribusi Frekuensi Responden

Berdasarkan Tingkat Kecemasan

Sebelum Terapi Storry Telling

di RSUP DR. M. Djamil

Padang Tahun 2017

\begin{tabular}{ccc}
\hline $\begin{array}{c}\text { Tingkat } \\
\text { Kecemasan }\end{array}$ & F & \% \\
\hline Tinggi & 4 & 40.0 \\
\hline Sedang & 6 & 60.0 \\
\hline Total & 10 & 100.0
\end{tabular}

Berdasarkan tabel 4.1 didapatkan bahwa sebelum diberikan terapi Storry Telling ditemukan lebih dari separuh dari anak yang menjalani hospitalisasi yaitu 6 orang (60.0\%) anak mengalami tingkat kecemasan sedang di RSUP Dr. M. Djamil Padang tahun 2017.

2. Tingkat Kecemasan Sesudah Terapi Storry Telling

Tabel 4.2

Distribusi Frekuensi Responden

Berdasarkan Tingkat Kecemasan

Sesudah Terapi Storry Telling Di RSUP DR. M. Djamil Padang Tahun 2017

\begin{tabular}{ccc}
\hline Tingkat Kecemasan & f & \% \\
\hline Sedang & 2 & 20.0 \\
\hline Rendah & 8 & 80.0 \\
\hline Total & 10 & 100.0
\end{tabular}

Berdasarkan tabel 4.2 didapatkan bahwa sesudah diberikan terapi Storry Telling ditemukan sebagian besar anak yang menjalani hospitalisasi yaitu sebanyak 8 orang $(80.0 \%)$ anak mengalami tingkat kecemasan rendah di RSUP Dr. M. Djamil Padang tahun 2017. 


\section{b. Analisa Bivariat}

Analisis bivariat bertujuan untuk melihat perbedaan tingkat kecemasan antara sebelum dan sesudah diberikan terapi Storry Telling.

Tabel 4.3

Pengaruh Story Telling Terhadap Tingkat Kecemasan Responden Di RSUP DR. M. Djamil Padang Tahun 2017

\begin{tabular}{|c|c|c|c|c|}
\hline Variabel & Kelompok & $\mathbf{N}$ & Mean & p value \\
\hline \multirow{2}{*}{$\begin{array}{l}\text { Tingkat } \\
\text { Kecemasan }\end{array}$} & Pre Test & & 19.7 & \\
\hline & Post Test & & 8.0 & \\
\hline
\end{tabular}

Tabel 4.3 menunjukkan bahwa uji statistik dengan uji wilcoxon didapatkan nilai $\mathrm{p}$ value = $0,007$ ( $\mathrm{p}<0,05)$. Hal ini menunjukkan bahwa ada pengaruh story telling terhadap tingkat kecemasan anak prasekolah yang menjalani hospitalisasi di RSUP Dr.M.DJAMIL Padang Tahun 2017.

\section{PEMBAHASAN}

\section{Analisis Univariat}

\section{Tingkat Kecemasan Sebelum Terapi Storry Telling}

Hasil penelitian menunjukkan bahwa sebelum terapi Storry Telling ditemukan sebanyak 6 orang $(60.0 \%)$ mengalami tingkat kecemasan sedang di RSUP Dr. M. Djamil Padang tahun 2017. Hasil penelitian ini sejalan dengan penelitian Rupdi Lumbansiantar (2012) tentang pengaruh storry telling terhadap tingkat kecemasan akibat hospitalisasi pada anak usia prasekolah di RSUD Bekasi menunjukan semua anak yang dihospitalisasi memiliki tingkat kecemasan yang berbeda- beda terdiri dari 21 orang $(56,4 \%)$ kecemasan sedang, 11 orang $(28,2 \%)$ kecemasan ringan, 6 orang $(15,4 \%)$ kecemasan berat. Perbedaan penelitian ini dengan penelitian Rupdi Lumbansiantar (2012) terletak pada sampel penelitian, serta tempat penelitian.

Ansietas atau kecemasan merupakan perasaan takut yang tidak jelas dan tidak didukung oleh situasi. Ketika merasa cemas, individu merasa tidak nyaman, takut atau mungkin memiliki firasat akan ditimpa malapetaka padahal ia tidak mengerti mengapa emosi yang mengancam tersebut terjadi. Tidak ada objek yang dapat diidentifikasi sebagai stimulus ansietas. Ansietas merupakan alat peringatan internal yang memberikan tanda bahaya kepada individu (Videbeck, 2008).

Terlihat sebelum diberikan terapi adanya responden yang mengalami kecemasan tinggi.
Hal ini terlihat dari hasil analisis kuesioner, dimana didapatkan data bahwa $100 \%$ responden menyatakan gelisah (pertanyaan no.14), $100 \%$ responden menyatakan sangat takut menghadapi hasil yang (pertanyaan no.16).

Menurut Safaria \& Saputra (2012), salah satu reaksi yang ditimbulkan oleh kecemasan adalah ; 1) Reaksi emosional, merupakan komponen kecemasan yang berkaitan dengan persepsi individu terhadap pengaruh psikologis dari kecemasan, seperti perasaan keprihatinan, ketegangan, sedih, mencela diri sendiri atau orang lain. 2) Reaksi kognitif, merupakan ketakutan dan kekhawatiran yang berpengaruh terhadap kemampuan berpikir jernih sehingga mengganggu dalam memecahkan masalah dan mengatasi tuntutan lingkungan sekitarnya dan 3) Reaksi fisiologis, merupakan reaksi yang ditampilkan oleh tubuh terhadap sumber ketakutan dan kekhawatiran. Reaksi ini berkaitan dengan sistem syaraf yang mengendalikan berbagai otot dan kelenjar tubuh sehingga timbul reaksi dalam bentuk jantung berdetak lebih keras, nafas bergerak lebih cepat, tekanan darah meningkat.

Tingkat kecemasan pada anak yang hospitalisasi ini dapat disebabkan oleh beberapa faktor. Sebagaimana disampaikan oleh Nursalam dkk. 2008) bahwa penyebab dari kecemasan dipengaruhi oleh banyak faktor, baik faktor dari petugas (perawat, dokter, dan tenaga kesehatan lainnya), lingkungan baru, maupun keluarga yang mendampingi selama perawatan. Keluarga sering merasa cemas dengan perkembangan keadaan anaknya, pengobatan dan biaya perawatan. Meskipun dampak tersebut tidak bersifat langsung terhadap anak, secara psikologi anak akan merasa perubahan perilaku dari orang tua yang mendampinginya selama perawatan.

Berdasarkan hal ini asumsi peneliti terhadap penelitian ini adalah ditemukan bahwa adanya anak yang mengalami tingkat kecemasan tinggi pada saat menjalani hospitalisasi di RSUP Dr. M. Djamil Padang. Hal ini dapat disebabkan karena anak tidak punya pengalaman dalam proses perawatan dan tidak tahu tentang prosedur tindakan sehingga menyebabkan timbulnya rasa cemasa pada anak selama menjalani proses hospitalisasi. Kondisi harus segera diatasi karena akan berdampak kurang baik terhadap psikologis anak bahkan bisa menyebabkan traumapada anak. Dalam hal ini perlu adanya peran petugas kesehatan dan dukungan keluarga terhadap anak berupa pemberian informasi tentang tindakan prosedur 
perawatan dan menyakinkan anak bahwa hal ini tidak perlu ditakuti sehingga tingkat kecemasan anak bisa berkurang. Hal lain juga dapat dilakukan melalui program terapi terhadap anak salah satunyaadalah terapi story telling yang diharapkan dapat membantu mengurangi tingkat kecemasan pada anak.

\section{Tingkat Kecemasan Sesudah Terapi Storry Telling}

Hasil penelitian menunjukkan bahwa sesudah terapi Storry Telling ditemukan sebanyak 2 orang $(20.0 \%)$ anak mengalami tingkat kecemasan sedang dan sebanyak 8 orang $(80.0 \%)$ anak mengalami tingkat kecemasan rendah di RSUP Dr. M. Djamil Padang tahun 2017. Hasil penelitian ini sejalan dengan penelitian yang dilakukan oleh Rupdi Lumbansiantar (2012) yang bertentang pengaruh storry telling terhadap tingkat kecemasan akibat hospitalisasi pada anak usia prasekolah di RSUD Bekasi menunjukan setelah dilakukan terapi bermain storry telling pada anak yang di hospitalisasi menunjukan bahwa 21 orang $(53,8 \%)$ pada kecemasan ringan, 14 orang $(35,9 \%)$, tidak cemas 4 orang $(10,3 \%)$, dan tidak ditemukan lagi anak yang mengalami kecemasan berat.

Terlihat pada penelitian setelah terapi story telling terjadi penurunan tingkat kecemasan pada anak, dimana tidak ada lagi anak yang mengalami tingkat kecemasan tinggi. Hal ini dapat disebabkan karena dengan dilakukan terapi story telling anak akan meras nyaman, senang dan terhibur sehingga tidak lagi memikirkan proses hospitalisasi sehinggadapat menurunkan tingkat kecemasan anak. Sesuai dengan pendapat Latif dkk (2014) bahwa storry telling merupakan sebuah terapi non farmakologi atau disebut juga dengan terapi tanpa menggunakan obat, yang bertujuan untuk membuat anak menjadi senang atau dijadikan suatu hiburan pada saat dirawat di rumah sakit selain itu storry telling bisa membantu perkembangan berbahasa dan berinteraksi dengan orang lain.

Menurut Mutterings (2012), storry telling merupakan cara bertutur, menyampaikan cerita atau memberikan penjelasan secara lisan. Storry telling merupakan kegiatan dalam menyampaikan peristiwa dalam kata-kata, gambar, dan suara. Ditambahkan oleh Latif dkk (2014) bahwa storry telling juga merupakan cara untuk menyampaikan nilai-nilai yang berlaku di masyarakat.

Berdasarkan hal ini maka asumsi peneliti terhadap penelitian ini adalah ditemukan bahwa adanya penurunan tingkat kecemasan pada anak yang menjalani hospitalisiasi setelah diberikan terapi strory telling. Dimana dengan bercerita akan membuat anak senang, nyaman dan terhibur sehingga dapat mengurangi tingkat kecemasan pada anak.

D. Analisa Bivariat

1. Pengaruh Terapi Story Telling Terhadap Tingkat Kecemasan Responden Di RSUP DR. M. Djamil Padang Tahun 2017

Hasil penelitian menunjukkan bahwa uji statistik dengan uji wilcoxon didapatkan nilai $\mathrm{p}$ value $=0,007 \quad(\mathrm{p}<0,05)$. Hal ini menunjukkan bahwa ada pengaruh terapi story telling terhadap tingkat kecemasan anak prasekolah yang menjalani hospitalisasi di RSUP Dr.M.DJAMIL Padang Tahun 2017.

Hasil penelitian ini sejalan dengan penelitian yang dilakukan oleh Rupdi Lumbansiantar (2012) tentang pengaruh storry telling terhadap tingkat kecemasan akibat hospitalisasi pada anak usia prasekolah di RSUD Bekasi. Hasil penelitian menunjukkan bahwa ada pengaruh storry telling terhadap tingkat kecemasan akibat hospitalisasi pada anak usia prasekolah.

Terbukti pada penelitian bahwa adanya pengaruh story telling terhadap tingkat kecemasan anak prasekolah yang menjalani hospitalisasi di RSUP Dr.M.DJAMIL Padang. Hal ini terlihat dari tingkat kecemasan yang dialami anak, dimana setelah diberikan terapi story telling terjadi penurunan rata - rata tingkat kecemasan pada anak sehingga anak tidak lagi mengalami tingkat kecemasan tinggi.

Sesuai dengan pendapat Latif dkk (2014) bahwa storry telling merupakan sebuah terapi non farmakologi atau disebut juga dengan terapi tanpa menggunakan obat, yang bertujuan untuk membuat anak menjadi senang atau dijadikan suatu hiburan pada saat dirawat di rumah sakit selain itu storry telling bisa membantu perkembangan berbahasa dan berinteraksi dengan orang lain. Dilanjutkan oleh Supartini (2014) bahwa bermain berfungsi untuk merangsang perkembangan sensorik-motorik, perkembangan intelektual, perkembangan sosial, perkembangan kreativitas, perkembangan kesadaran diri, perkembangan moral, dan bermain juga dapat digunakan sebagai terapi.

George w. Burns, mengemukakan beberapa kekuatan cerita yaitu untuk menumbuhkan sikap disiplin, membangkitkan emosi, memberi inspirasi, memunculkan perubahan, menumbuhkan kekuatan pikiran tubuh, menyembuhkan. Selain itu cerita dapat memberikan pengaruh yang besar bagi pikiran dan emosional apalagi jika cerita tersebut 
benar-benar terjadi atau nyata (Irmawaty, 2013 ). Cerita yang menarik dapat memberikan, pandangan tentang rasa percaya diri, rasa aman, tentram, menanamkan rasa peka dalam batinnya untuk bisa membedakan mana yang baik dan yang buruk, menanamkan kesadaran tentang kebenaran dan keadilan, keberanian, kejujuran, kesetiaan, pengorbanan, dan kehormatan. Cerita juga berfungsi untuk memperkaya pendaharaan kata anak-anak, menjadikan anak terampil dalam berbahasa selain lisan dan tulis, dan mengajarkan anak untuk dapat berbicara (Rosdiana, 2008).

Berdasarkan hal ini maka analisa peneliti terhadap penelitian ini adalah terbukti bahwa terapi story telling efektif untuk menurunkan tingkat kecemasan pada anak. Dimana sebelum diberikan terapi rata -rata tingkat kecemasan anak tinggi sehingga anak mengalami tingakt kecemasan tinggi. Namun setelah diberikan terapi terjadi penurunan nilai rata - rata tingkat kecemasan anak sehingga tidak adalagi yang mengalami tingkat kecemasn tinggi dan rata - rata anak hanya mengalami tingkat kecemasan rendah.

\section{KESIMPULAN}

Setelah dilakukan penelitian pada 10 orang responden tentang pengaruh story telling terhadap tingkat kecemasan anak prasekolah yang menjalani hospitalisasi di RSUP Dr.M.DJAMIL Padang Tahun 2017, maka dapat disimpulkan: Sebelum diberikan terapi Storry Telling ditemukan lebih dari separuh dari anak yang menjalani hospitalisasi yaitu 6 orang $(60.0 \%)$ anak mengalami tingkat kecemasan sedang di RSUP Dr. M. Djamil Padang tahun 2017. Sesudah diberikan terapi Storry Telling ditemukan sebagian besar anak yang menjalani hospitalisasi yaitu sebanyak 8 orang $(80.0 \%)$ anak mengalami tingkat kecemasan rendah di RSUP Dr. M. Djamil Padang tahun 2017. Ada pengaruh story telling terhadap tingkat kecemasan anak prasekolah yang menjalani hospitalisasi di RSUP Dr.M.DJAMIL Padang Tahun 2017 ( $\mathrm{p}=0,007$ ).

Disarankan kepada petugas kesehatan yang merawat anak untuk menerapkan terapi story telling pada anak sehingga dapat menurunkan tingkat kecemasan pada anak. Kepada peneliti selanjutnya disarankan untuk melakukan penelitian lebih lanjut tentang terapi storry telling agar dapat menurunkan tingkat kecemasan anak yang menjalani hospitalisasi.

\section{DAFTAR PUSTAKA}

Apriany, D. 2013. Hubungan antara hospitalisasi anak dengan tongkat kecemasan orangtua.(http://jks.fikes.unsoed.ac.id/index.p hp/jks/article/download/477/246, diperoleh 11 Maret, 2017)
Apriliawati, Kaluas Inggrith, dkk. 2015. Perbedaan terapi bermain puzzle dan bercerita terhadap kecemasan anak usia prasekolah (3-6 Tahun) selama hospitalisasi di ruang anak RS TK.III.R.W. Mongisidi Manado, 3(2), 2

Edisaputra, S.P.N. 2012. Effect of playing therapy using storry telling technique to anxiety caused by hospitalization in preschool children at menur ward of Dr. Soeradji Tirtonegoro hospital Klaten, halaman 3-5, diperoleh 11 Maret, 2017)

Hawari, D. ( Eds 2), 2013. Manajemen stres cemas dan depresi, Jakarta : Badan Penerbit FKUI

Hendy, Z. 2010. Pembelajaran sastra untuk umum, Jakarta : PT Gramedia

Hidayat, A.A. 2009. Pengantar ilmu keperawatan anak 1, Jakarta: Salemba Medika

Irmawaty Lenny. 2013. Pengaruh storry telling terhadap tingkat kecemasan akibat hospitalisasi pada anak usia prasekolah di RSUD kota Bekasi 2013. Halaman 2-3, diperoleh 11 Maret, 2017)

Latif, M, dkk. 2014. Orientasi baru pendidikan anak usia dini, Jakarta : Kencana

Mutterings. 2012. Cerita Rakyat, Struktur dan nilai moral serta model pelestariannya. Oleh perpusatakaan Universitas Pendidikan Indonesia. Halaman 13-32, diperoleh 11 Maret, 2017)

Mutiah, D. 2012. Psikologi bermain anak usia dini, Jakarta : Kencana

Mutterings, F. 2012. Storrytelling or how to make people care about anything, Italy : Asisi

NHDS. Saprudin, N. 2016. Efektifitas terapi bermain puzzle dengan mewarnai gambar terhadap tingkat kecemasan anak usia prasekolah di RSUD 45 Kuningan halaman 2, diperoleh 11 Maret, 2017

Nursalam, dkk. 2008. Asuhan keperawatan bayi dan anak, Jakarta : Salemba Medika

Riyadi, S \& Sukarmin. 2013 Asuhan keperawatan pada anak, Yogyakarta: Graha Ilmu

Rifka, 2016. Superlengkap koleksi terbaik dongeng dunia, Yogyakarta: Supala Cemerlang

Rupdi Lumbasiantar. 2012. Pengaruh storry telling terhadap tingkat kecemasan akibat hospitalisasi pada anak usia prasekolah di 
RSUD kota Bekasi, 2012 halaman 2-5, diperoleh 11 Maret, 2017)

Rosdiana, Y. 2008. Bahasa dan sastra Indonesia di SD, Jakarta: Universitas Terbuka

Safaria, T \& Saputra, E.S, 2009. Manajemen emosi, Jakarta: PT Bumi Aksara

Soetjiningsih. 2015. Tumbuh Kembang Anak, Jakarta: Penerbit buku kedokteran EGC

Sugiyono. 2016. Metode penelitian, Bandung : Alfabeta, cv
Supartini, Y. 2014. Konsep dasar keperawatan anak, Jakarta : Penerbit buku kedokteran EGC

Susenas. Saprudin, N. 2016. Efektifitas terapi bermain puzzle dengan mewarnai gambar terhadap tingkat kecemasan anak usia prasekolah di RSUD 45 Kuningan, halaman 3, diperoleh 11 Maret, 2017)

Triton, PB. 2008. Tips cerdas meengasuh balita, Jakarta : Oryza

Videbeck, L.S. 2008. Buku keperawatan jiwa, Jakarta: Penerbit buku kedokteran EGC 